\title{
Perceptions of Regulation on the UK Mortgage Market: A Step Too
} Far?

\author{
Ehsan Khansalar ${ }^{1}$, Natasha Turner ${ }^{1} \&$ George Giannopoulos ${ }^{1}$ \\ ${ }^{1}$ Kingston Business School, Kingston University, London, UK \\ Correspondence: Ehsan Khansalar, Kingston Business School, Kingston University, London, UK. E-mail: \\ khansalarehsan@yahoo.com
}

Received: December 28, 2015

Accepted: June 11, 2015

Online Published: July 22, 2015

doi:10.5539/ijbm.v10n8p59

URL: http://dx.doi.org/10.5539/ijbm.v10n8p59

\begin{abstract}
Poor risk management within firms was the result of deregulation and the Big Bang of 1986. Without a regulator and in order to achieve financial growth, firms inadequately managed their risk. The 2007 financial crisis was a wake up call to the UK highlighting that companies could not carry on in this manner. The financial crisis resulted in the FSA assuming the role of an active regulator, thus many requirements were implemented including the Capital Adequacy Ratio. Consequently, gross mortgage lending decreased by $63 \%$ during 2007-2010. Therefore, this study investigates the perceptions of the current level of regulation on the UK mortgage market. The research found there is a strong perception that the level of regulation is hindering lending and competition within the market.

More specifically this study uses a qualitative approach of in-depth interviews with five financial and regulatory professionals. The results suggest that two professionals perceived regulation as positive for the UK mortgage market. Regulation is perceived positively because of its ability to give consumers greater market confidence, the implementation of loss mitigation strategies that prevent house repossession and the loss of irresponsible lenders. Three professionals perceived regulation as highly negative because it has reduced the lending rate, created barriers to entry thus reducing competition, has moved careless lending to other areas of the market such as payday loans, has created a substantial cost burden, has used a one-size-fits-all approach and has not removed fraudulent activity completely.

Overall these results suggest that UK economy may struggle to get out of this recessionary period as long as there are uniform capital requirements imposed on UK lenders. It is recommended that the regulator may take an approach that lessens the requirements enforced on non-bank lenders. However, the capital requirements should be imposed on banks that have wider implications for the UK economy and caused the current financial crisis in order to prevent future financial crises. Another recommendation is the segmentation of building societies from banks as seen in the 1970s. The separation would create market confidence and would result in greater local knowledge; this would stimulate growth within the UK mortgage market.
\end{abstract}

Keywords: mortgage market, regulation, UK

\section{Introduction}

\subsection{Background}

This study explores how regulation is affecting the UK mortgage market. The study has been conducted by interviewing five professionals from financial and regulatory backgrounds about their perceptions of the Financial Services Authority's (FSA's) regulation on the mortgage market. The FSA regulates the mortgage market as well as all financial services markets, exchanges and firms within the UK. They set the standards that firms must meet and will fine the firms that fail to meet requirements. As an independent body, the FSA receives no government funding so is therefore it is solely funded by the fines received from regulating firms (FSA, 2012). However, the industry has not always been regulated; it was not until the Financial Services and Markets Act 2000 that the single market regulator, the FSA was created (FSA, 2012). Although the FSA has regulated the market since early 2001, it is widely accepted by the industry that they initially took a light touch approach to regulation.

The FSA's initial light touch approach to regulation resulted in poor risk management within firms. Many firms 
took an irresponsible attitude towards lending and lent without verifying customer income (Walker, 2010). Customers faced with unsuitable mortgages, coupled with the vast amounts being lent, meant that firms did not have sufficient financial resources to carry on operating when customers struggled with mortgage repayments. Thus, following on from the 2007 financial crisis and to encourage better management of risk, the FSA introduced minimum capital requirements. The Capital Adequacy Ratio (CAR) measures the balance between available capital and risky assets to ensure an adequate amount of capital is available. The ratio splits capital into two tiers in an approach that enables the monitoring of quality as well as quantity. Generally the amount of capital to be held is $8 \%$ of assets with $4.5 \%$ being made up of tier 1 capital. However, the largest most systemically important banks need to hold $9.5 \%$ of tier 1 capital, as well as further tier 2 capital (FSA, 2011).

\subsection{Research Motivation}

The FSA reacted to the 2007 financial crisis by assuming the role of an active regulator. They implemented many requirements as demonstrated by their 8000-page handbook, including the previously mentioned minimum capital requirement (FSA Handbook, 2013). A minimum capital requirement helps to ensure that lenders have enough capital to prevent market uncertainty and thus reduces the risk of another financial crisis. The importance of this is highlighted by Royal Bank of Scotland's (RBS's) failure. The FSA found that market uncertainty due to poor liquidity was crucial to RBS's failure (FSA, 2011). At the end of 2007, RBS had a tier 1 capital adequacy of $1.97 \%$. Under current Basel III requirements RBS would be expected to hold tier 1 capital of 9.5\% (FSA, 2011). Therefore, there is a clear need for regulation due to the financial failures that occur without market regulation. However, Figure 1.1 below shows a $63 \%$ decrease in gross mortgage lending during 2007-2010. This indicates that consumers are struggling to gain access to the mortgage market. In part this is due to increased regulation, which has forced lenders to take extreme precaution in whom they lend to whilst meeting minimum capital requirements.

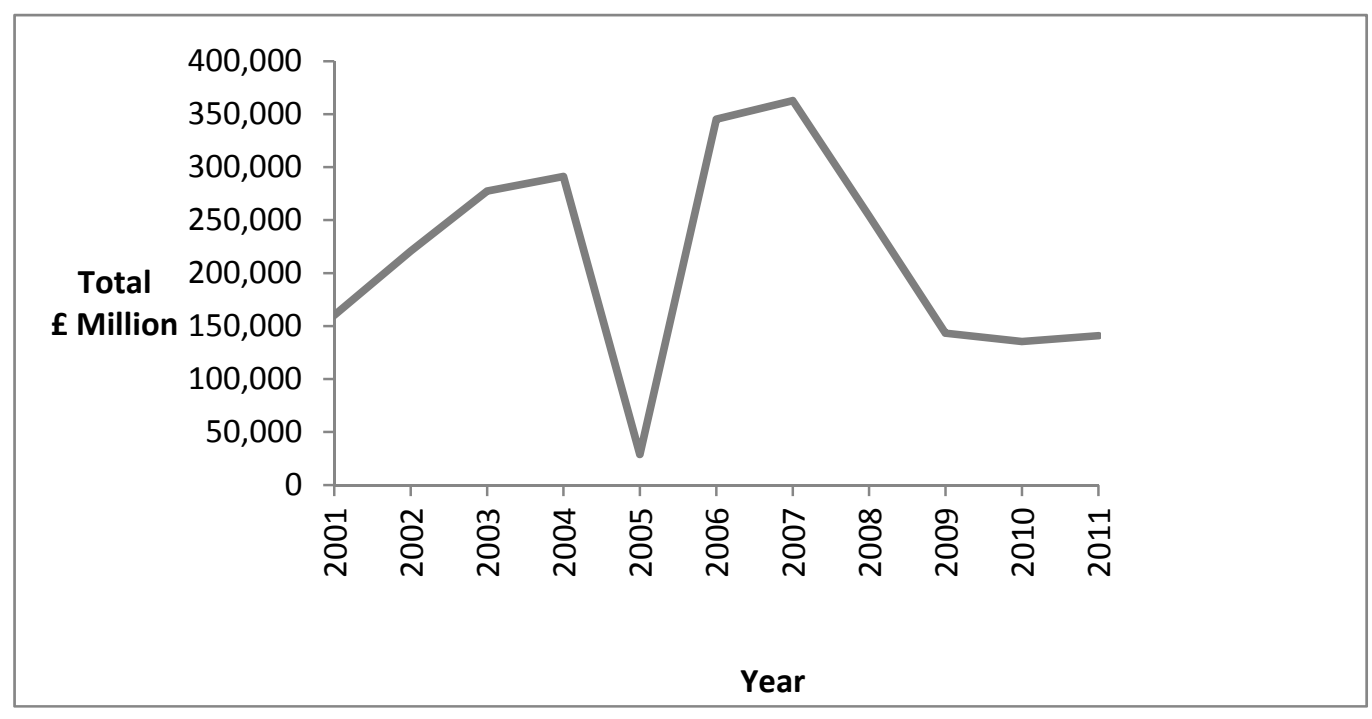

Figure 1. Gross mortgage lending in the UK from 2001 to 2011

(Data sourced from Council of Mortgage Lenders, 2012).

Additionally, regulation has reduced competition within the mortgage market thus decreasing gross mortgage lending. Increased regulation has forced many niche and specialist lenders from the market as demonstrated by the number of specialist lenders falling by 92\% between 2007 and 2009 (CML, 2010). Furthermore, capital requirements have forced many smaller lenders from the market who simply cannot meet such requirements. This has resulted in $78 \%$ of new business being accounted for by the top 6 mortgage lenders (Financial Advice, 2013). Consequently, a large firm such as Tesco was delayed from entering the market due to regulation surrounding its product offerings (Shoffman, 2010). It is concerning that a large firm with a wealth of capital resources struggled to enter the market. These examples demonstrate that regulation has heavily impacted competition within the market by forcing small and specialist lenders out of the market and creating an environment where even large companies struggle to gain access.

Although the decrease in gross mortgage lending is linked to increased regulation, it would be arbitrary to 
assume that this was the only reason for the decrease. The reduction is also linked to a decrease in demand due to the UK economy entering a recession and unemployment rising (CML, 2010). It is acknowledged that both supply and demand factors of mortgage lending are interlinked which contributed to the decrease in gross mortgage lending. However, this study focuses on the impact of regulation as being the factor that has decreased gross mortgage lending.

RBS's failure demonstrates that there is a need for regulation due to poor risk management that occurs without regulation. On the other hand, the decrease in gross mortgage lending shows that regulation has had a negative impact on the market. Therefore, the research objective of this study is to explore how the current level of regulation on the UK mortgage market is perceived. The results indicate a strong perception that lending and competition within the UK mortgage market have been hindered by regulation. However, the research results also suggest a need for regulation in the form of rescue schemes to prevent repossession and the reassurance to consumers of being sold affordable mortgages.

\subsection{Structure}

The rest of this study is structured as follows: Section Two reviews the literature on the mortgage market. Section Three outlines the research methodology used to investigate the research objectives of this study. The findings of this study are presented in section Four. This is followed by an analysis of the results in section Five. Finally, section Six concludes this paper, discusses this research limitations and provides suggestions for future research.

\section{Literature Review}

\subsection{Introduction}

This section discusses the conceptual literature reviews on the UK mortgage market. There is evidence that is has undergone a transformation. Initially the mortgage market was entirely separate from the banking industry and it was comprised of lenders known as building societies. The first sub-section of the literature review explains how deregulation led to the mortgage market becoming entwined with banking. The second sub-section demonstrates that the reshape of building societies was one of the factors that led to the financial crisis thus resulting in the empowerment of the FSA. Next sub-section presents details on how capital requirements have impacted the mortgage market historically; this provides a basis for understanding the implications of the current capital requirement. Finally, the perception of the current capital requirement is assessed by the means of present literature.

\subsection{Background on the UK Mortgage Market}

A series of mergers in the early 1900s led to the formation of five major banks: Barclays Bank, Midland Bank, Westminster Bank, Lloyds Bank and the National Provincial Bank (Saunders \& Wilson, 1999). There was a fear of monopolisation within the industry but the banks assured they would not merge any further which prevented a legal ruling (Busch, 2009, p. 127). Despite the mergers, commercial banks took no interest in the housing and mortgage markets (Coleman, 1996, p. 177). This created space for building societies, which gained 90 per cent of the housing and mortgage market by 1970 (Busch, 2009, p. 133).

The building society sector up until the 1970s was structured considerably different to the commercial bank sector. The building society sector was full of diversity and comprised of national groups, medium-sized, small-sized and even single-branched local competitors (Busch, 2009, p. 133). The benefit of local building societies was the in-depth market knowledge acquired by managers and employees who typically lived in the area that they worked in. Additionally, customers were encouraged to save at their local building societies thus building trust and improving their credit rating. This helped to assess whether a mortgage should be given to a customer, and whether it would provide feasible returns for the building society. In-depth knowledge of the customer and the local area contributed to building societies earning much more than banks. This was demonstrated by Valnek (1999) who found that building societies received a higher return on assets than banks did. The high returns that building societies were experiencing encouraged the banks to enter the market. Subsequently, in 1980 the UK Government imposed regulatory changes to lift the restrictions on banks entering the mortgage market (Coombes et al., 1997).

"The 1980s saw the introduction of government moves....to deregulate and liberalise financial institutions and markets in order to encourage greater competition and efficiency. One result of these changes has been that the previously separate circuits of mortgage finance have become increasingly integrated into the wider circuits of finance capital" (Hamnett, 1994).

The Big Bang in 1986 completely reshaped the banking sector by deregulating the industry. Furthermore, The 
Building Societies Act 1986 deregulated the sector by the way of demutualisation; this allowed the conversion of a building society into an investor-owned commercial company. The effects of the Big Bang of 1986 resulted in a wave of acquisitions and mergers amongst banks, commercial banks and building societies. The power of issuing mortgages which had previously fell with building societies was now heavily within the power of the banks. For borrowers, this loss of building societies resulted in higher costs of loans and the closure of many local knowledgeable branches (Cook et al., 2002). Table 2 below demonstrates the demutualisation and mergers that contributed to the loss of building societies.

Table 2. Historical changes within the building society industry

\begin{tabular}{ll}
\hline Date & Change within the building society movement \\
\hline June 1989 & Abbey National converts to bank status and becomes a plc. \\
April 1994 & Lloyds Bank announces take-over of Cheltenham \& Gloucester building society. \\
November 1994 & Halifax and Leeds announce merger and conversion to a bank. \\
July 1995 & The take-over of the National \& Provincial Building Society by the Abbey National announced. \\
January 1996 & Woolwich announces conversion to bank status by becoming a plc. \\
February 1996 & Alliance \& Leicester announces conversion to a plc. \\
April 1996 & Northern Rock announces conversion to a plc. \\
\hline
\end{tabular}

(Data extracted from Coombes et al., 1997).

Instead of increasing competition as Hamnett (1994) suggested, the deregulation reduced mortgage market competitiveness through not enough decentralisation of power, money and resources. Furthermore, the multinational banks had little understanding of local markets, which meant they lent too much to people who could not afford it. The loss of the building societies and gaining of power for the banks created an environment where banks could lend significantly larger amounts of money than they were previously able to.

The Big Bang created a cutthroat environment where some banks were competing for mortgage business by offering significantly low interest rates. Some even lending at rates below cost, which opened them up to interest rate risk. So, deregulation created an environment where banks were open to two types of risk: credit risk of large mortgages not being repaid and interest rate risk. Therefore, the Big Bang of 1986 created an unstable marketplace that played a part in causing the 2007 financial crisis (The Guardian, 2011).

Following the 2007 financial crisis, the market became heavily regulated. The FSA introduced many requirements in order to prevent future financial failures. One of the requirements implemented by the FSA was the previously mentioned Capital Adequacy Ratio. The following sub-section discusses how capital requirements have affected the mortgage market historically. This is followed by a sub-section discussing the current capital requirements and how this is affecting the mortgage market. By looking at the historical impact of capital requirements one can get insights into the effect of the current capital requirements on the mortgage market.

\subsection{The Historical Impact of Capital Requirements}

The literature over the past 20 years demonstrates the impact that capital requirements have had on the mortgage market historically. The literature identifies that capital requirements in the past have impacted negatively upon the market, which suggests that the current CAR is hindering the mortgage market. The Basel Capital Accord implemented in 1988 required banks and non-bank lenders to hold minimum capital of $8 \%$ (Bank of International Settlements, 2009). Among others, Peterson and Wall (1995) suggest that this capital requirement led to the 1990-1991 credit crunch.

Peterson and Wall (1995) found that banks were under increasing pressure from 1990-1992 to conform to levels of capital regulation. This sharply reduced the lending rate and contributed directly to the credit crunch of 1990-1991. Peterson and Wall used a quantitative approach in their study. However, they discovered that banks felt pressured by regulation despite this pressure being demonstrated by the preceding credit crunch. A quantitative approach seems to have limited the information that they discovered. Therefore a quantitative approach has been deemed unsuitable for this study due to the desire to provide more information on how regulation is affecting the mortgage market at present.

EU's regulation has changed the UK regulatory framework by the means of the revised Basel Capital Accord-Basel II. Within the EU all deposit takers had to implement Basel II by 1 January 2008 (Council of 
Mortgage Lenders, 2010). Basel II took a three-pillar approach and used a calculation of risk to determine the level of capital to hold. This approach encouraged firms to sell risky assets (IFLR, 2008). Basel II's calculation of risk approach was a significant development in the financial industry. Berger and Udell (1994), Peterson and Wall (1995) had both previously condemned similar treatments to create safer banks. In hindsight this may have been the worse time to implement Basel II as it only added to the financial difficulties being experienced by all banks and lenders at the time.

\subsection{Current Capital Requirements}

The FSA incorporates legislation from the Basel Committee due to the UK being part of the EU. Requirements from the Basel Committee are implemented by European legislation and subsequently through the FSA Handbook (FSA, 2011). Basel III-a revised version of the previously mentioned Basel II; started its gradual implementation in January 2013 (Deloitte, 2013). Due to Basel III requirements, the FSA implemented capital resource requirements in the form of the Capital Adequacy Ratio (CAR). The ratio measures the balance between available capital and risky assets to ensure firms have the ability to operate without causing disruption to the UK economy. The ratio is shown below:

\section{Capital Adequacy Ratio: Tier 1 Capital + Tier 2 Capital \\ Risk Weighted Assets}

Splitting capital into tiers assesses the quality of the capital. The FSA state that the quality of capital is just as important as the quantity (FSA, 2011). The minimum capital adequacy is $8 \%$ however Basel III states that over half of this must be made up of tier 1 capital. Tier 1 capital includes common shares, share premiums and retained earnings; therefore it is considered of higher quality and must measure at least $4.5 \%$ of the risk-weighted assets (BIS, 2011). Deloitte (2013) state that capital requirements will increase gradually until 2019 when it will reach $10.5 \%$ of total capital expressed in risk-weighted assets. The main issue is that as previously mentioned, banks were already struggling with previous capital requirements. However, by changing the quality of capital and slowly increasing the requirement, Basel III imposes even tougher requirements on mortgage lenders than have been implemented in the past. The RBS, BIS and Deloitte reports are all considered with high regard and importance due to their close link to the source of regulation.

\subsection{Summary}

The review of the literature, which is dominated by Basel I and Basel II capital requirements, demonstrates the negative effect these capital requirements have had on the mortgage market. The objective of this study is to evaluate the impact of current capital requirements on mortgage market, which are set out recently by FSA, and are related with Basel III capital requirements.

\section{Research Methodology}

This study follows an interpretive research approach because participants have been interviewed in order to gauge their perception of the level of regulation on the industry. An interpretive sociology approach has been deemed suitable because the research is being conducted with people and not objects (Lewis et al., 2009, p. 116). Symbolic interactionism is assumed through interviewing social actors in order to interpret the level of regulation on the mortgage market. Therefore, the ontology of the research follows a subjective approach that the social phenomenon of the research is created from the perceptions of the social actors. The epistemology assumed is in line with the philosophy and takes the attitudes and feelings of social actors as acceptable knowledge (Lewis et al., 2009, p. 113).

A mono method choice has been adopted of collecting qualitative data through face-to-face interviews. A qualitative approach has been deemed appropriate because previous literature studies such as Peterson and Wall (1995) drew limited conclusions from their quantitative study. Therefore, in order to explore further the effects of regulation on mortgage market, a qualitative approach of in-depth interview techniques is more suitable. Additionally, the research question is exploring the 'perceptions' of regulation. A perception approach is linked to qualitative research because it enables the gauging of feelings around the subject matter. Quantitative research collects numbers therefore it may not be easy to understand the perception of regulation through numerical data.

Five professionals have been interviewed and they have been made unidentifiable in line with ethical reasons. Each professional comes from a different type of financial or regulatory background, which gives a rounded analysis of regulation within the mortgage market. By maximizing the variance between each professional in the sample this increases the insight into the effect of regulation (Rubin \& Rubin, 1995).

The aim of each interview was to assess how each professional perceived the level of regulation on the UK 
Mortgage Market. Therefore, open-ended questions have been used in order to prevent misleading each professional to give biased answers. The mining technique used by the interviewer enables the interviewee to express their true experiences while at the same time not being led by the questions. The interviews are based around the effect that regulation has had on each professional and the business that they work in. This provides the opportunity for the professional to explain positive and negative effects thus helping to form a hypothesis of how the level of regulation is perceived.

Appendix 2 demonstrates the guideline for the interview questions. However, the questions changed depending on the answers given by the interviewee and vary slightly between each professional because they all have different backgrounds. For example, the questions for professional A are geared towards the specifics of regulation while the questions for professional $\mathrm{D}$ are focused on the effect that regulation has had on accountants. The interviews were recorded which allowed for transcripts to be produced. Transcripts enabled the interviewer to reflect on the answers given during the interview.

Once the data was transcribed it was analysed by restructuring the answers into positive and negative implications of regulation. By looking at both positive and negative aspects this helps to get insights into how the level of regulation is perceived. Assessing both positive and negative aspects prevents biased results from forming. Additionally, the discussions are summarised using verbatim quotations to avoid manipulation of answers.

\section{Findings}

\subsection{Introduction}

This section presents the main findings of the interviews with five professionals in the mortgage market.

\subsection{Interview One: Professional A}

Interview one was conducted with an employee from the Council of Mortgage Lenders (CML). The CML act as the voice of the mortgage market within the UK and liaise with the FSA to relay information back to lenders.

The participant highlighted that "the thing that consumers should feel more comfortable about is that they're not going to have the burden of the fail in full" if another financial crisis was to occur. Additionally, he suggested, "consumers should feel empowered" in regards to knowing that regulation is there to support them.

The participant highlighted many concerns regarding competition. "Some of the smaller societies in particular and lenders may find it difficult to cope with all the new regulation and the burdens placed upon them and I think that their ability to fund within this market and to survive will be very difficult and certainly their ability to grow will practically disappear". The participant thought regulation offers "an opportunity for larger lenders if they wish to grow via consolidation" due to smaller lenders being unable to fund themselves, however he feared this would reduce competition further.

The participant was concerned that the liquidity changes in particular have had a "huge impact on firms" and thus a "huge impact on the UK financial services industry and their ability to lend" to consumers. In terms of consumers ability to get a mortgage the participant thought they had "reduced access as a whole". He also feared that "those costs of regulation will be funded ultimately by consumers particularly if lenders are selling less product". Furthermore, the participant thought "the impacts of the Mortgage Market Review (MMR) will be miniscule in comparison to the impacts of the Capital Requirements Directive IV (CRD IV) because of the additional capital and the quality of capital that you have to hold." Therefore, once CRD IV comes in to action gross mortgage lending will reduce even further.

The participant was also concerned about Tesco's struggle in entering the market. He was concerned that it took them over two years to enter the market so "it's difficult to see how other smaller more niche entrants that can serve different parts of the market will enter or even larger mainstream players".

The participant stated that the FSA "had definitely taken a differential approach to building societies, banks and non-bank lenders and I feel that the broader rescue package that was provided to the industry definitely discriminates". He stated, "non-bank lenders have not received a penny of support, and banks and building societies and particularly larger banks have quite significantly benefited from bailouts and broader kind of support by the Bank of England in particular".

\subsection{Interview Two: Professional B}

Interview Two was conducted with an employee who works within a Reserves team. The Reserves team was chosen because they have seen a vast amount of regulatory changes due to the nature of the work that they do: setting aside a portion of earnings to cover any anticipated losses. During the financial crisis they would have 
seen a significant change in the amount of expected losses.

The participant highlighted several benefits for consumers such as the implementation of loss mitigation strategies "schemes like mortgage rescue schemes, government schemes to keep you in your home to stop companies repossessing you". Another benefit to customers is, "should...a company go under or struggle... the regulation forces the company to have a big enough capital pool available for customers". Thus, significantly reducing the amount of risk faced by customers.

A view of the participant was that the FSA have not actually "done much". Although the participant explained, "they've come out with the MMR, but that came out and never really went anywhere. They decided to split into two parts and I don't think that's resolved, but it doesn't seem like they're doing a lot to be honest". Another issue raised was that although the FSA have reduced careless lending in the subprime mortgage market, "now you get pay day loans and lenders" which will likely target the same credit impaired customers of the subprime mortgage market, thus transferring the risk elsewhere. The participant was concerned that when the economy picks up, the careless-lending that was previously seen could return; however he stated that he "would have to see what occurs once the economy does pick up".

\subsection{Interview Three: Professional C}

Interview Three was conducted with a member of the Compliance department because this department is responsible for ensuring compliance with regulation. The participant stated that as a functional team they had become "more proactive, we cannot afford to be reactive". He also expressed his understanding of the level of interaction expected from the FSA and how as a team they have to be well prepared for this much before it happens. The participant stated that he could expect the FSA "to intervene at earlier stages, product development for example". This means for the Compliance department they have to "understand the systems and controls around the new product, and the products are fit for purpose and comply with Treating Customers Fairly (TCF) principles, so we've had to engage far more actively". In regards to the impact that regulation has had on customers, the participant thought there had not been an impact on the customers yet because, "it's still at the very early stages". However he expected the regulation to impact them "medium to long term...hopefully in terms of a better product deliver, better service, better interaction with them".

In terms of the costs involved of complying with regulation, the participant stated that the "principle cost has been resource focused". He said that there are twenty-eight employees in the department "whom a lot of their time has been spent getting involved in the thematics in terms of reviewing the files we're sending to the FSA". The participant was asked whether a more sustainable industry had been created because of the regulation however he thought it was "too early to say". He thought that the MMR might result in some unintended consequences "where the approach taken is one size fits all".

\subsection{Interview Four: Professional D}

Interview Four was conducted with an auditor of an accounting firm. Auditors have had increased contact with firms and the FSA since the increased regulation as firms rely on auditors to advise them. Professional D thought a positive implication of regulation was the lack of access to the market for those that could not afford to repay the mortgage. The participant also thought that regulation has a positive impact on consumers because it meant, "losing a lot of the 'cowboys' and people who were not making an effort to comply". The participant anticipates that the loss of poor market players will result in a greater economy. Furthermore, she thought regulation was positive for the companies that could comply because it means a "stronger control environment and making sure you don't get frauds...slipups and...bad reporting". Additionally, the participant believes "the potential for collapse should be reduced" by regulation. She hopes it can increase market consumer confidence, which will ultimately stimulate the growth of the UK economy.

The participant spoke about the increased cost burden for clients and stated, "bottom line is the cost". The participant spoke about the types of costs incurred by clients due to regulation:

1). Educating the Board and the management team on complying with RDR, and

2). Changing their fee structure because you can't do it on commission anymore, you can't do it upfront, it's got to be relative to what work they've provided or done so they had to invest money in that.

3). They've paid us on the value added tax (VAT) side, to review the VAT impact of new charging methods, renegotiating VAT.

It was stated, "A lot of companies would have had to spend quite a lot of money paying firms like us". The participant was clear that the cost of regulation "to these firms has been quite a lot". She stated that regulation 
has caused a lot of independent financial advisor's IFA's to go out of business. In regards to the whole industry the participant stated that increased costs had decreased profit margins which meant, "more people are going out of business", resulting in a reduction of competition. The participant thought that smaller firms "just don't have the time and resource to grow a team of specialists", which will impact upon their ability to grow and compete with larger firms.

In regards to consumers, the participant thought, "the impact of this extra regulation is less people can get mortgages". Furthermore, the participant thought that regulation is "a massive barrier to people starting up". Overall, the participant thought "it's gone too far, I think we had none which is bad, then we had some which starts to become positive if the cost is there but the benefit is there too, I actually think we've now gone too much".

The participant identified a key issue is that current regulation is "a mass of regulation covering everything", instead of it being broken down by sector and industry. Another issue identified was the amount of legislation from outside of the UK such as EU and US "that is now impacting UK businesses where they have to put controls in place to be able to report to the US". Despite the regulation the participant thought that in the future, people who want to commit fraud can "find another way of doing it...the regulations are only correcting what we've noticed is wrong". The participant believes this will lead to even more regulation in the future once further wrong doings are noticed.

\subsection{Interview Five: Professional E}

Interview Five was conducted with an employee of an accounting firm who had previously worked at the FSA and could therefore provide extensive information on the regulator of the UK mortgage market.

The participant thought, "firms are now starting to think of regulation as good but with increased costs". The participant offered some rationale that the increased cost is "just the cost of being an international firm, a large firm and working in different jurisdictions".

The participant thought, "costs to comply with regulation have gone up". He thought this was an issue for smaller building societies, smaller businesses and credit unions that have not got "spare cash to spend on compliance with regulation". The result of the increased costs to all firms has been to shrink profit margins. However, he thought, "There's just too much regulation at the moment".

The participant spoke about the "prudential rule which means firms now actually have to raise a lot of extra capital, to raise extra capital they have to find somewhere but the liquidity isn't there in the market". Changes to regulation have meant "what used to be previously capital-some of those instruments don't count as capital; others will count for very little and the quality of what counts as capital, the bar has also increased, so things that were perfectly fine in the previous regime are probably not capital". An extremely significant piece of information from the participant was that "in the next three years...the five large banks in the UK have to raise $£ 80$ billion from somewhere" due to the prudential regulations.

The participant thought that a clear problem of the level of regulation is that "mortgages obviously are down and the government is trying to give different incentives for banks". However, it would seem the incentives are failing to make an impact on the market.

Despite the regulation, the participant stated that "firms just find different ways of getting round the rules", which long-term poses a risk for the stability of the market. Another issue highlighted was that many firms are struggling with the level of regulation to the point that firms say "we just don't know what is a priority". The participant thought the way the regulation was brought in was an issue because it took on "a big bang approach, everything at the same time" which was "a knee-jerk reaction to what happened in 2007/2008". The participant thought the future still holds potential problems due to "the waterbed effect-you fix something here but then something else will spring up somewhere else".

\subsection{Summary}

In addition to the effects that regulation has on consumers and competition there were several other findings highlighted by the participants. The results of this study identify that professionals B and C found mostly positive implications of regulation on the UK mortgage market including:

1). Implementation of loss mitigation strategies,

2). Reduction in the amount of risk faced by consumers,

3). Greater understanding of all business functions due to FSA intervention, 
4). Long term benefits to consumers such as better products and better service.

While professionals A, D and E provided mostly negative implications including:

1). High costs,

2). One-size-fits-all approach,

3). Discrimination against the mortgage market,

4).The possibility that fraudulent activity will still occur,

The aforementioned results are analysed in the following section.

\section{Discussion and Analysis of the Results}

\subsection{Introduction}

In this section interviews' results are analysed in the light of the conceptual theories and current mortgage market issues. The results are not conclusive due to the small sample size used. However, the results have explored the perceptions of regulation in the mortgage market, which could assist further research in the subject matter.

\subsection{Analysis of the Results}

Both professionals $\mathrm{B}$ and $\mathrm{C}$ had a positive perception of regulation and its effect on the UK mortgage market. This may have been influenced by both participants working in the same business and thus seeing the effects of regulation in a different way to the other participants. For example, professional A communicates directly with the FSA, his job is to understand regulation and support lenders by communicating regulation to them. Therefore he is much more involved with regulation and can see the effects of it more than professionals B and C. Furthermore, professionals D and $\mathrm{E}$ appear to have much more involvement with regulation than professionals $\mathrm{B}$ and $\mathrm{C}$, hence there being a divide in perceptions amongst the sample.

This study found that there was a strong perception that regulation and more specifically capital requirements have decreased gross mortgage lending. Professionals A, D and E all spoke of the negative impacts that capital requirements have had. Professional A thought there had already been a 'huge impact' on lending and his perception was that future regulation would decrease lending even further. Professional D thought that regulation meant less people could get mortgages, which is consistent with Bradshaw (2012). Similarly, professional E spoke of the capital requirements and indicated that in the next three years the five largest UK banks need to generate $£ 80$ billion of capital. This poses great concern, as Peterson and Wall (1995) found that banks struggling with liquidity requirements resulted in the 1990-1991 credit crunch. Gross mortgage lending has already decreased significantly; therefore it is concerning that the largest banks have to generate even more capital. Having to generate such a substantial amount of capital is likely to have even further negative implications on gross mortgage lending.

In regards to competition, both professionals $\mathrm{A}$ and $\mathrm{D}$ believe it has been reduced by regulation and more specifically by capital requirements. Professional A thought that smaller societies and lenders are struggling to survive let alone grow under current regulation. Similarly, professional D thought that regulation had resulted in increased costs, which had forced many out of business thus reducing competition. This is consistent with the lack of competition as identified by the Council of Mortgage Lenders (CML) (2010). Furthermore, Shoffman (2010) stated that Tesco had delayed its entry to the mortgage market because of regulatory issues. Similarly, professional A expressed his concern that this signifies an extreme loss of competition within the market for more niche players that would find it even harder than Tesco to enter the market. Thus, the participant is right to be concerned about significant barriers of entry to the UK mortgage market, which will only reduce competition further.

Despite the negative implications of regulation, the participants perceptions were consistent with the theory that regulation is needed due to the poor risk management that can occur as found by the RBS report (FSA, 2011). Professional A's perception was that consumers can benefit from knowing they should not feel the effects of poor risk management if a firm was to fail. Professional B highlighted that a benefit to consumers was the implementation of loss mitigation strategies, so even if a firm has taken a risk by giving them an unsuitable mortgage the customer is unlikely to face repossession. Similarly, as Walker (2010) discovered, many consumers were being given mortgages without having their income verified. Therefore, professional D's perception that regulation prevents people from being given mortgages who cannot afford it denotes a strong benefit of regulation.

Thus far the results have analysed the perceptions of regulation on lending, competition and the need for 
regulation due to poor risk management. These were anticipated perceptions of regulation on the mortgage market. Additional perceptions are highlighted by the participants in this study are analysed next.

The participant's perceptions of the regulatory approach were similar. They all thought that the FSA had become far more intrusive whereas pre-crisis the regulator had taken a 'light touch' approach. Regulation was identified as being a 'knee-jerk' reaction to the 2007 financial crisis. Beattie, Brandt, and Fearnley (2002) had warned against hasty post-Enron action, but the perception of regulation by professional $\mathrm{E}$ as a 'knee-jerk' reaction suggests the previous warning was ignored.

Professionals C, D and E perceived that regulation has taken a 'one-size-fits-all' approach, which was not suitable for the market. The perception was that this approach was hindering not just the mortgage market but also the whole financial services industry and ultimately the UK economy. A similar treatment for risky and safe banks was condemned by Berger and Udell (1994) and Peterson and Wall (1995). Therefore, this suggests that the one-size-fits-all approach that has been applied to the whole financial industry is resulting in negative implications as demonstrated by the decrease in gross mortgage lending.

Professionals E and D perceived that despite the regulation there will always be fraudulent activity occurring. This is consistent with Arthur and Booth (2006) who found that financial scandals increase as state regulation tightens. Suggesting that despite all this regulation, the number of scandals is equally increasing. Similarly, professionals $\mathrm{E}$ and $\mathrm{B}$ had the perception that despite regulation reducing careless mortgage lending, this careless lending would just be transferred to another part of the market. An example of this occurring in the market is the increase in 'payday loans' that typically offers APR of 5853\% (Wonga, 2013). Thus suggesting that regulation has pushed careless lending to another part of the market.

\subsection{Summary}

The analysis of the results showed a strong perception that regulation is hindering the mortgage market. However, the results also provide several positive implications of regulation. The next section concludes this study, presents research limitations and makes suggestions for future research on further assessment of the implications of regulation on the UK mortgage market.

\section{Conclusion}

\subsection{Recommendations}

There is an apparent need for a regulator of the UK mortgage market because the absence of a regulator resulted in poor risk management which led to the financial crisis of 2007. Without regulation, financial firms open themselves up to risk such as credit risk and interest rate risk. Regulation forces firms to report ratios to the FSA and thus ensure they are not being affected by such risks. However, the current minimum capital requirements mean that they have to hold significantly higher capital than has ever previously been required. As a result this is prohibiting the growth of the UK mortgage market, but even more worryingly has serious implications for the UK economy. Historical research such as Peterson and Wall (1995) found that capital requirements of the Basel Capital Accord led to the recession of 1990-1991. Therefore, it would appear that the UK economy will struggle to get out of the recessionary period as long as there are uniform capital requirements imposed on UK lenders. In particular, on one side the regulator should take an approach that lessens the requirements enforced on non-bank lenders, as they do not participate in risky investments and have minimum impact on the UK economy. On the other side current capital requirements should be imposed on banks that have wider implications for the UK economy and caused the financial crisis in order to prevent future financial crises.

The current level of regulation has had serious implications for the level of competition within the mortgage market. Larger firms have the ability to invest in compliance teams and are able to grow their business, while smaller firms either have to consolidate or face the risk of going out of business. This is worrying for credit-impaired consumers who could previously be serviced by these smaller niche firms.

The results of this study also suggest that a one-size-fits-all approach to regulation has failed to increase market confidence. The UK mortgage market would benefit from a definite segmentation of building societies from banks as seen in the 1970s. The separation of building societies from the banking industry would create market confidence and would result in greater local knowledge; this would stimulate growth within the UK mortgage market.

Finally the results of this study suggest that even though the risk of market failing has been reduced because of the increased regulation, it would be unwise to assume that fraudulent activities have equally reduced. They are still on going and it will only be a matter of time until they come to the surface. The real test will be whether the market manages to survive. 


\subsection{Research Limitations}

One of the research limitations of this study is the small sample size used (five interviews) so the results may not be statistically conclusive. Another limitation is that the participants of the study were asked marginally different questions. Therefore, the study could be adapted by seeking professionals from the same backgrounds and asking them the same questions to obtain consistent answers.

\subsection{Further Research}

A wider sample size could be used in a quantitative approach to test the level of regulation on the UK mortgage market. It would be also interesting to investigate the percentage of financial firms that are passing the capital requirements. Research could then test whether there is any correlation to the amount of lending being carried out by the financial firms. Also, as mentioned earlier, the FSA is gradually increasing capital requirements up until 2019. Therefore, an interesting study would be a longitudinal one, which assesses how firms cope with these changes. It is anticipated that these increases would decrease mortgage lending even further. Finally, a study of the effects of the regulation on the whole financial service industry could be carried out instead of just focusing on the mortgage market using a quantitative and/or qualitative approach.

\section{References}

Arthur, T., \& Booth, P. (2006). Financial regulation, the state and the market: is the financial services authority an unnecessary evil? Economic Affairs, 26(2), 22-30.

Bank of International Settlements. (2009). History of the Basel Committee and its Membership. Retrieved from http://www.bis.org/bcbs/history.pdf

Bank of International Settlements. (2011). Basel III: A global regulatory framework for more resilient banks and banking systems. Retrieved from http://www.bis.org/publ/bcbs189.pdf

Beattie, V., Brandt, R., \& Fearnley, S. (2002). Financial regulation of public limited companies in the UK: A way forward post-Enron. Journal of Financial Regulation and Compliance, 10(3), 254-265.

Berger, A. K., \& Udell, G. F. (1994). Did risk-based capital allocate bank credit and cause a "credit crunch" in the U.S.? Journal of Money Credit and Banking, 26(3), 585-628.

Bradshaw, J. (2012). Stagnation in mortgage market through 2012. Retrieved from http://www.ftadviser.com/2012/01/09/investments/economic-indicators/stagnation-in-mortgage-market-thro ugh-0w1zrCfB1 oatUQAuqUbKpL/article.html

Busch, A. (2009). Banking Regulation and Globalization. Oxford: Oxford University Press.

Coleman, W. D. (1996). Financial Services, Globalization and Domestic Policy Change: A Comparison of North America and the European Union. London: Macmillan.

Cook, J., Deakin, S., \& Hughes, A. (2002). Mutuality and Corporate Governance: The Evolution of UK Building Societies Following Deregulation. Journal of Corporate Law Studies, 2(1), 110-138.

Coombes, M., Marshall, J. N., Raybould, S., \& Richardson, R. (1997). The transformation of the British building society movement: Managerial divisions and corporate reorganization, 1986-1997. Geoforum, 28(3-4), 271-288.

Council of Mortgage Lenders. (2010). The decline in lending: a question of demand or supply? Retrieved from http://www.cml.org.uk/cml/publications/newsandviews/79/286

Council of Mortgage Lenders. (2012). Gross mortgage lending at 11-month high in October. Retrieved from Retrieved from http://www.cml.org.uk/cml/media/press/3345

Deloitte. (2013). Timeline of Basel III implementation. Retrieved from $\mathrm{http}: / /$ www.deloitte.com/view/en_NL/nl/industries/financial-services-industries/basel/timeline

Financial Advice. (2013). Is competition reducing in the UK mortgage market? Retrieved from http://www.financialadvice.co.uk/news/7/mortgages/11731/is-competition-reducing-in-the-uk-mortgage-ma rket.html

FSA Handbook. (2009). Tailored Handbooks. Retrieved from http://fsahandbook.info/FSA/select-handbook/tailored

FSA Handbook. (2013). Prudential sourcebook for Mortgage and Home Finance Firms, and Insurance Intermediaries. Retrieved from http://media.fsahandbook.info/pdf/MIPRU.pdf 
FSA. (2010). Mortgage Market Review: Responsible Lending. Retrieved from $\mathrm{http} / / /$ www.fsa.gov.uk/pubs/cp/cp10_16.pdf

FSA. (2011). The failure of the Royal Bank of Scotland. Retrieved from http://www.fsa.gov.uk/pubs/other/rbs.pdf

FSA. (2012). Who are we? Retrieved from http://www.fsa.gov.uk/about/who

Hamnett, C. (1994). Restructuring housing finance and the housing market. In M. R. Corbridge, R. Martin \& N. Thrift (Eds.), Money Power Space (pp. 281-308). Blackwell, Oxford.

IFLR. (2008). Give Basel II a chance. Retrieved from http://www.iflr.com/Article/2072550/Give-Basel-II-a-chance.html

Lewis, P., Saunders, M., \& Thornhill, A. (2009). Research methods for business students. England: Pearson Education Limited.

Peterson, D. R., \& Wall, L. D. (1995). Bank holding company capital targets in the early 1990s: The regulators versus the markets. Journal of Banking \& Finance, 19(3), 563-574.

Rubin, H., \& Rubin, I. (1995). Qualitative interviewing: The art of hearing data. CA: Sage.

Saunders, A., \& Wilson, B. (1999). The impact of consolidation and safety-net support on Canadian, US and UK banks: 1893-1992. Journal of Banking \& Finance, 23(2-4), 537-571.

Shoffman, M. (2010). Tesco delays entry into mortgage market. Retrieved from http://www.ftadviser.com/2011/10/27/mortgages/mortgage-products/tesco-delays-entry-into-mortgage-mark et-ISv1JLfZ3A4K65CfDc0z0N/article.html

The Guardian. (2011). Big Bang's shockwaves left us with today's big bust. Retrieved from http://www.guardian.co.uk/business/2011/oct/09/big-bang-1986-city-deregulation-boom-bust

Valnek, T. (1999). The comparative performance of mutual building societies and stock retail banks. Journal of Banking \& Finance, 23(6), 925-938.

Walker, N. (2010). FSA statistics need to be on an even par. Retrieved from http://www.ftadviser.com/2011/10/27/regulation/regulators/letter-fsa-statistics-need-to-be-on-an-even-par-O ZDVad3pNYHTYgBIUgjKrK/article.html

Wonga. (2013). Home. Retrieved from http://www.wonga.com

Zafar, A. (2010). FSA unveils mortgage reform blueprint. Retrieved from http://www.ftadviser.com/2011/10/27/ifa-industry/fsa-unveils-mortgage-reform-blueprint-QIqv1YvfhWKP8 kCYLQpKeI/article.html

Zafar, A. (2011). Outlook dim for UK, European mortgage market: poll. Retrieved from http://www.ftadviser.com/2011/10/14/ifa-industry/outlook-dim-for-uk-european-mortgage-market-poll-KT D7zDxWa5GE23hcAnJHEK/article.html

\section{Appendices}

Appendix 1: MCOB Requirements

Mortgages and Home Finance: Conduct of Business sourcebook

MCOB1

MCOB applies to every firm that carries on regulated mortgage activities. MCOB applies to regulated mortgage contracts entered into on or after 31 October 2004.

\section{MCOB2}

A firm should have regard to the customer's knowledge of the home finance transaction to which the information relates

MCOB3

Financial promotions must not be misleading, small print must not mislead. Must not communicate during unsocial hours.

\section{MCOB4}

A firm must take reasonable steps to ensure that the scope of the service given to a customer, and the regulated 
mortgage contracts offered, is based on a selection from one of the following:

(a) the whole market; or

(b) a limited number of mortgage lenders; or

(c) a single mortgage lender

\section{MCOB5}

Before a home finance transaction decision is made the customer must be provided with information, which enables comparability between offers. The customer must be aware of the price that the customer will be required to pay under that home finance transaction, to enable the customer to assess whether it is affordable to him.

\section{MCOB6}

Regulated sale and rent back agreements

\section{MCOB7}

Information must be provided to customers to enable them to keep track of payments

\section{MCOB8}

Equity release transactions

MCOB9

Equity release: product disclosure

MCOB10

Firms must use the proper application of APR.

\section{MCOB11}

A firm must be able to show that before deciding to enter into, or making a further advance on, a regulated mortgage contract, or home purchase plan, account was taken of the customer's ability to repay. Firms must also have a responsible lending policy.

\section{MCOB12}

The FSA will expect a firm to ensure that charges made to a customer arising from the sale of a repossessed property and charges arising in relation to a sale shortfall are not excessive and are subject to the same considerations as apply with respect to arrears charges under this chapter.

\section{MCOB13}

(1) A firm must deal fairly with any customer who:

(a) is in arrears on a regulated mortgage contract; or

(b) has a mortgage shortfall debt.

(2) A firm must put in place, and operate in accordance with a written policy (agreed by its respective governing body) and procedures for complying with (1).

Appendix 2: Guideline interview questions

1. How has the increase in regulation affected the business from a (compliance/risk/reserves etc.) point of view?

2. What has been the cost to the company and has this been beneficial to the company?

3. What is the biggest change that (compliance/risk/reserves etc.) has had to make in order to comply with the new regulation?

4. How have these changes impacted upon customers?

5. Has your day-to-day activity changed from pre to post crisis?

6. Is a more sustainable industry being created due to these changes?

7. Is careless lending decreasing and how is this measured?

8. Do you think this has an effect on first-time buyers?

9. Has this created opportunities for the business? E.g. cleaner book 
10. Has this created threats to the business?

\section{Copyrights}

Copyright for this article is retained by the author(s), with first publication rights granted to the journal.

This is an open-access article distributed under the terms and conditions of the Creative Commons Attribution license (http://creativecommons.org/licenses/by/3.0/). 